\title{
Pengembangan Perangkat Pembelajaran Aljabar Berbasis Problem Based Learning untuk Mendukung Kemampuan Komunikasi Matematika Siswa Sekolah Menengah Pertama
}

\author{
Sri Winarni ${ }^{1, a)}$, Marlina $^{1}$ \\ ${ }^{1}$ Universitas Jambi \\ Jl. Lintas Sumatera Jambi - Muara Bulian Km. 15, Mendalo Darat, Jambi Luar Kota, Muaro Jambi, Jambi, \\ Indonesia, 36122 \\ a) sri.winarni@unja.ac.id
}

\begin{abstract}
The purpose of this research is to develop learning tools based for Algebra on Problem Based Learning (PBL) to support the mathematics communication ability of Junior High School students. Learning tools developed in this development research is students' worksheets. The research method used is 4D model, which consists of 4 stages, namely define, design, develop, and disseminate. The results of worksheets' validation by experts were 4,05 for the layout design and 4,19 for the content (both were categorized as valid). In addition, the students respons that the students' worksheets were practical (with average of 3,94) and the teacher responses that these were very practical (with average of 4,23). Thus, based on the expert validation as well as the students and teacher of mathematics responses, the learning tools developed have already met the criteria of valid and practical and ready for the field testing to see its effectiveness on students' mathematics communication ability.
\end{abstract}

Keywords: Algebra; learning tools; mathematical communication; Problem Based Learning

\begin{abstract}
Abstrak: Tujuan dari penelitian ini adalah mengembangkan perangkat pembelajaran Aljabar berbasis Problem Based Learning (PBL) untuk mendukung kemampuan komunikasi matematika siswa SMP. Perangkat pembelajaran yang dikembangkan dalam penelitian ini adalah Lembar Kerja Siswa (LKS). Model pengembangan perangkat pembelajaran yang digunakan adalah model 4-D yang terdiri dari tahap define, design, develop, dan disseminate. Hasil validasi ahli terhadap desain dan materi LKS masing-masing 4,05 dan 4,19 dengan kriteria valid. Selain itu, rata-rata respon siswa terhadap penggunaan LKS adalah 3,94 dengan kriteria praktis dan ratarata respons guru matematika terhadap LKS adalah 4,23 atau pada kriteria sangat praktis. Berdasarkan validasi ahli, respons guru dan siswa dapat disimpulkan bahwa perangkat pembelajaran yang dikembangkan layak diujicobakan di lapangan untuk melihat keefektifannya terhadap kemampuan komunikasi matematika siswa.
\end{abstract}

Kata Kunci: Aljabar; komunikasi matematika; perangkat pembelajaran; Problem Based Learning 


\section{PENDAHULUAN}

Matematika merupakan mata pelajaran yang diajarkan mulai pendidikan dasar sampai perguruan tinggi. Matematika sebagai pelayan (servant) bagi ilmu-ilmu lain, karena matematika adalah ilmu dasar yang mendasari dan melayani berbagai ilmu pengetahuan lainnya (Supatmono, 2009). Matematika pada hakikatnya adalah sebuah bahasa yang menggunakan simbol dan aturanaturan yang telah disepakati terutama pada materi aljabar. Aljabar merupakan sebuah bidang kajian dalam matematika juga dapat disebut sebagai bahasa. Aljabar merupakan salah satu cabang penting dari matematika, karena aljabar dapat bermanfaat dalam kehidupan sehari-hari, sebagai alat penyelesaian masalah bidang matematika lainnya dan dalam ilmu lainnya.

Materi aljabar sarat dengan berbagai unsur dan simbol matematis yang mempunyai nama, makna, dan definisi yang berbeda-beda. Menurut Soedjadi (2000), dengan beberapa simbol, matematika dapat mengungkapkan suatu pengertian yang cukup luas. Untuk mengungkapkan makna dari simbol-simbol matematika tersebut diperlukan salah satu kemampuan yaitu kemampuan komunikasi matematika. Guerreiro dalam Izzati dan Suryadi (2010) juga mengungkapkan bahwa komunikasi matematika merupakan alat bantu dalam transmisi pengetahuan matematika atau sebagai fondasi dalam membangun pengetahuan matematika.

Komunikasi matematika itu sangat perlu dimiliki oleh siswa agar siswa mampu mengkomunikasikan, memberitahukan, menjelaskan, suatu gagasan yang mereka miliki kepada siswa lainnya (Deswita, Kusumah \& Dahlan, 2018). Dengan begitu terciptalah suasana pembelajaran yang komunikatif dan menyenangkan melalui diskusi siswa yang saling berkomunikasi dan bertukar pikiran untuk memecahkan suatu permasalahan. Kemampuan komunikasi matematika dalam kegiatan pembelajaran di kelas juga akan menciptakan terjalinnya komunikasi yang baik antara guru dan siswa atau sebaliknya, dan antara siswa dengan siswa lainnya (Anggralia, Deswita, Erita, Habibi \& Putra, 2019).

Pengembangan kemampuan matematika siswa sesuai dengan standar komunikasi pada pembelajaran materi aljabar bukanlah perkara mudah. Fakta menunjukkan bahwa para siswa mengalami kesulitan dalam mempelajari aljabar. Karena materi aljabar memuat konsep dan ide abstrak serta sarat dengan berbagai unsur dan simbol matematis yang mempunyai nama, makna, dan definisi yang berbeda-beda. Aktivitas guru dalam proses pembelajaran serta sikap siswa itu sendiri sangat mempengaruhi proses dan hasil belajar aljabar. Peran guru sangat penting dalam mendukung komunikasi matematika siswa dalam pembelajaran aljabar.

Oleh karena itu, sebelum melaksanakan pembelajaran guru harus menyusun perencanaan pembelajaran. Menurut Sanjaya (2011) perencanaan pembelajaran adalah proses pengambilan keputusan terhadap hasil berpikir guru seacara rasional tentang sasaran dan tujuan pembelajaran, 
serta rangkaian kegiatan yang harus dilaksanakan untuk mencapai tujuan tersebut dengan memanfaatkan segala potensi dan sumber belajar yang ada. Hasil akhirnya tersusun dokumendokumen yang dijadikan acuan dalam melaksanakan proses pembelajaran. Dokumen-dokumen tersebut berupa perangkat pembelajaran yang terdiri dari silabus, RPP, bahan ajar, LKS dan instrumen penilaian.

Berdasarkan pengalaman peneliti, sebagian guru menganggap perangkat pembelajaran masih sebagai pelengkap administrasi. Padahal perangkat pembelajaran merupakan acuan dalam melaksanakan proses pembelajaran. Sehingga dalam menyusun perangkat pembelajaran tersebut guru harus memperhatikan lingkungan-lingkungan pembelajaran, mempelajari respon-respon siswa, dan belajar dari pengalaman. Hal ini menjadi dasar bagi guru untuk memilih pendekatan pembelajaran yang tepat untuk siswa sehingga bisa memiliki kemampuan komunikasi matematika yang bagus.

Salah satu model pembelajaran yang dapat meningkatkan kemampuan komunikasi matematika siswa adalah Problem Based Learning (PBL). Menurut Nur (2011), "model Pembelajaran Berbasis Masalah (PBL) adalah model pembelajaran yang memberikan kesempatan kepada siswa menyelidiki dan mempelajari situasi-situasi masalah otentik dan bermakna." Dengan menggunakan PBL, proses pembelajaran dapat dioptimalkan melalui LKS yang digunakan, penggunaan media pembelajaran yang sesuai, dan pengelolaan kelas yang baik. Hal ini sejalan dengan penelitian yang menyatakan bahwa terdapat pengaruh penerapan model PBL berbantuan media pembelajaran terhadap kemampuan komunikasi matematika, kemampuan penalaran, kemampuan pemahaman konsep dan pemecahan masalah matematika siswa (Sartika, 2017; Wulansari, Putra, Rusliah \& Habibi, 2019; Elita, Habibi, Putra \& Ulandari, 2019)

Tahapan pendekatan PBL menurut Nur (2011) ada lima fase. Pertama, mengorientasikan peserta didik pada masalah. Pada tahapan ini guru memberikan penjelasan mengenai tujuan pembelajaran sekaligus memotivasi peserta didik untuk terlibat langsung dalam pembelajaran yang berisi soal-soal pemecahan masalah. Kedua, mengorganisasikan peserta didik untuk belajar. Pada tahapan ini guru mempunya fungsi yang mengatur tugas belajar peserta didik untuk memecahkan masalah yang dihadapinya. Ketiga, membantu penyelidikan mandiri dan kelompok. Pada tahapan ini guru memberikan bimbingan dan bantuan kepada peserta didik agar dapat mengumpulkan informasi yang sesuai untuk mencari penjelasan dan solusi dari masalah yang dihadapi, sehingga siswa dapat berdiskusi antar siswa untuk mengungkapkan ide-ide gagasan matematikanya. Keempat, mengembangkan dan menyajikan hasil karya serta memamerkannya. Pada tahapan ini guru membantu peserta didik untuk menyampaikan dan mengkomunikasikan hasil diskusi dengan teman-temannya ke depan kelas. Dan kelima, menganalisis dan mengevaluasi proses pemecahan masalah. Tahapan ini merupakan refleksi setelah melaksanakan pembelajaran berbasis masalah 
yang dilakukan oleh peserta didik. Dengan terlaksananya langkah-langkah PBL tersebut siswa diharapkan dapat mengkomunikasikan ide-ide matematikanya antar siswa dalam kelompoknya dan teman-temannya di depan kelas. Hal ini sejalan dengan penelitian Nurbaiti (2016) bahwa model PBL juga dapat meningkatkan kemampuan komunikasi matematika dan motivasi belajar siswa. Model PBL juga dapat meningkatkan komunikasi matematika dan pemecahan masalah (Duskri, Maidiyah, Risnawati \& Ilham, 2017), bahkan model PBL dapat meningkatkan komunikasi matematika dan kepercayaan diri siswa (Kumala, Waluyo \& Siswanto, 2019).

Agar penerapan model PBL lebih efektif untuk meningkatkan komunikasi matematika, perlu dikembangkan perangkat pembelajaran aljabar berbasis PBL yaitu silabus dan RPP yang merupakan bagian perencanaan guru dalam melaksanakan pembelajaran dan LKS sebagai petunjuk kerja untuk siswa bekerja secara tertulis sehingga siswa bisa mengungkapkan ide-ide matematika baik secara tertulis maupun lisan ketika diskusi dan presentasi. Tujuan dari penelitian ini adalah untuk mengembangkan perangkat pembelajaran aljabar berbasis PBL yang mendukung kemampuan komunikasi siswa SMP baik secara tertulis maupun lisan.

\section{METODE}

Penelitian ini merupakan penelitian dan pengembangan dengan model pengembangan 4-D. Model pengembangan 4-D (Four D) dikembangkan oleh Thiagarajan (1974) yang terdiri atas 4 tahap utama yaitu (1) Define, menganalis permasalahan berbagai kajian matematika sekolah menengah, (2) Design, merancang perangkat pembelajaran, (3) Develop, pengembangan perangkat pembelajaran dengan validasi ahli, uji coba kelompok kecil untuk mengetahui respon guru dan siswa, dan (4) Disseminate. Rancangan/prosedur penelitian ini dapat dilihat pada Gambar 1.

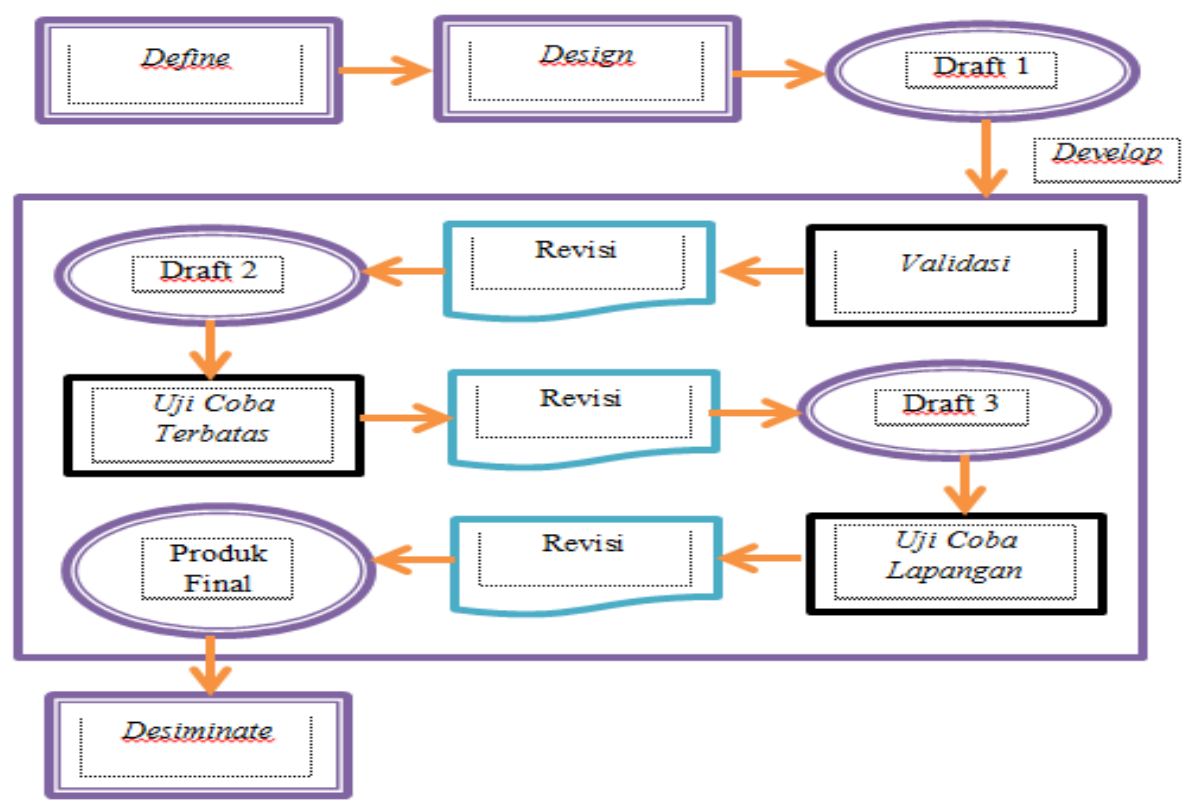

Gambar 1. Rancangan/prosedur penelitian 
Instrumen pengumpulan data pada penelitian pengembangan ini terdiri dari lembar validasi ahli terhadap perangkat pembelajaran dan lembar penilaian kepraktisan oleh guru dan siswa. Data kevalidan berupa skor yang diperoleh dari para ahli melalui lembar validasi serta data kepraktisan dari respon guru dan siswa dijumlahkan dan dikonversikan menjadi data kualitatif dengan 5 kriteria seperti yang ditunjukkan pada Tabel 1.

Tabel 1. Konversi data Kuantitatif ke Kualitatif dengan 5 Kriteria untuk Validitas ahli

\begin{tabular}{ccc}
\hline Interval & Rentang Skor & Kriteria \\
\hline $\mathrm{X}>\overline{\mathrm{X}}_{\bar{i}}+1,8 S b_{i}$ & $\bar{x}>4,2$ & Sangat Baik \\
\hline $\mathrm{X}_{i}+0,6 S b_{i}<X \leq \overline{\mathrm{X}}_{i}+1,8 S b_{i}$ & $3,4<\bar{x} \leq 4,2$ & Baik \\
\hline $\mathrm{X}_{i}-0,6 S b_{i}<X \leq \overline{\mathrm{X}}_{i}+0,6 S b_{i}$ & $2,6<\bar{x} \leq 3,4$ & Cukup Baik \\
\hline $\mathrm{X}_{i}-1,8 S b_{i}<X \leq \overline{\mathrm{X}}_{i}-0,6 S b_{i}$ & $1,8<\bar{x} \leq 2,6$ & Kurang Baik \\
\hline $\mathrm{X} \leq \overline{\mathrm{X}}_{i}-1,8 S b_{i}$ & $\bar{x} \leq 1,8$ & Sangat Kurang \\
\hline
\end{tabular}

Keterangan: X: Skor empirik, $\mathrm{X}_{i}$ : Rata-rata ideal, $S b_{i}$ : Standar deviasi ideal

\section{HASIL DAN PEMBAHASAN}

Berdasarkan tahap define yang terdiri dari analisis awal-akhir, karakteristik siswa, konsep, tugas dan tujuan pembelajaran, diperoleh informasi bahwa siswa masih kesulitan untuk mengungkapkan ide-ide matematika kepada sesama siswa dan guru karena guru terlalu dominan dalam proses belajar mengajar. Sehingga perlu didesain perangkat pembelajaran yang memberi peluang bagi siswa untuk mengkomunikasikan ide-ide matematika. Peneliti mendesain perangkat pembelajaran aljabar berbasis PBL untuk mendukung kemampuan komunikasi matematika. Keterkaitan antara langkah-langkah PBL dengan indikator komunikasi matematika dapat dilihat pada Tabel 2.

Tabel 2. Keterkaitan Langkah-langkah PBL dengan Indikator Komunikasi Matematika

\begin{tabular}{|c|c|c|}
\hline No. & Langkah-langkah dan Aktivitas PBL & $\begin{array}{c}\text { Indikator dan Aktivitas Komunikasi } \\
\text { Matematika }\end{array}$ \\
\hline 1. & $\begin{array}{l}\text { Mengorientasikan peserta didik pada masalah } \\
\text { Guru memberikan penjelasan mengenai tujuan } \\
\text { pembelajaran, memotivasi peserta didik untuk terlibat } \\
\text { langsung dalam pembelajaran yang berisi soal-soal } \\
\text { pemecahan masalah }\end{array}$ & \\
\hline 2. & 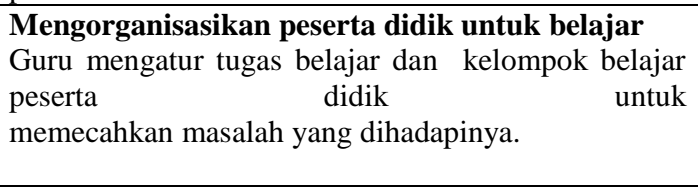 & $\begin{array}{l}\text { Memberikan tugas-tugas yang cukup memadai } \\
\text { (untuk membuat siswa maupun kelompok diskusi } \\
\text { lebih aktif). } \\
\text { Mengatur dan menggabungkan pemikiran } \\
\text { matematis siswa melalui komunikasi }\end{array}$ \\
\hline 3. & $\begin{array}{l}\text { Membantu penyelidikan mandiri dan kelompok } \\
\text { Guru memberikan bimbingan dan bantuan kepada } \\
\text { peserta } \\
\text { dapat mengumpulkan informasi yang }\end{array}$ & $\begin{array}{l}\text { Menciptakan lingkungan yang kondusif agar siswa } \\
\text { bisa dengan leluasa untuk mengungkapkan } \\
\text { gagasan-gagasannya. } \\
\text { Mengkomunikasikan pemikiran matematika secara }\end{array}$ \\
\hline
\end{tabular}




\begin{tabular}{|c|c|c|}
\hline No. & Langkah-langkah dan Aktivitas PBL & $\begin{array}{c}\text { Indikator dan Aktivitas Komunikasi } \\
\text { Matematika }\end{array}$ \\
\hline & $\begin{array}{l}\text { mencari penjelasan dan solusi dari masalah yang } \\
\text { dihadapi. }\end{array}$ & $\begin{array}{l}\text { koheren dan jelas kepada teman, guru dan orang } \\
\text { lain }\end{array}$ \\
\hline 4. & $\begin{array}{l}\text { Mengembangkan dan menyajikan hasil karya } \\
\text { serta memamerkannya } \\
\text { Guru membantu peserta didik untuk menyampaikan } \\
\text { dan mengkomunikasikan hasil diskusi dengan teman- } \\
\text { temannya ke depan kelas }\end{array}$ & $\begin{array}{l}\text { Mengarahkan siswa untuk menjelaskan dan } \\
\text { memberi argumentasi pada hasil yang diberikan } \\
\text { dan gagasan-gagasan yang dipikirkan. } \\
\text { Mengkomunikasikan pemikiran matematika secara } \\
\text { koheren dan jelas kepada teman, guru dan orang } \\
\text { lain }\end{array}$ \\
\hline 5. & $\begin{array}{l}\text { Menganalisis dan mengevaluasi proses pemecahan } \\
\text { masalah. } \\
\text { Refleksi setelah melaksanakan pembelajaran berbasis } \\
\text { masalah yang dilakukan oleh peserta didik. }\end{array}$ & $\begin{array}{l}\text { Mengarahkan siswa agar aktif memproses } \\
\text { berbagai macam ide dan gagasan. } \\
\text { Menganalisa dan menilai pemikiran dan strategi } \\
\text { matematis orang lain } \\
\begin{array}{l}\text { Menggunakan bahasa matematika untuk } \\
\text { menyatakan ide matematika dengan tepat. }\end{array}\end{array}$ \\
\hline
\end{tabular}

Berdasarkan Tabel 2, didesain perangkat pembelajaran aljabar berbasis PBL yaitu Silabus, RPP dan LKS. LKS yang dikembangkan terdiri dari beberapa pokok bahasan yaitu bentuk aljabar, persamaan dan pertidaksamaan linear satu variabel, perbandingan senilai dan aritmatika sosial. Setiap pokok bahasan terdiri dari beberapa kegiatan. LKS yang dikembangkan mengikuti langkahlangkah dan aktivitas PBL sehingga dapat memunculkan indikator dan aktivitas komunikasi matematika baik secara lisan maupun tulisan.

Sebelum memasuki fase-fase PBL untuk mengenal bentuk aljabar, siswa diingatkan kembali konsep-konsep perkalian bilangan bulat dalam kehidupan sehari-hari yang merupakan bahwa konsep perkalian didapatkan dari penjumlahan berulang. Sehingga memudahkan guru untuk mengarahkan siswa bahwa perkalian dengan sebarang bilangan yang bisa kita ganti dengan penulisan huruf. Huruf-huruf tersebut dinamakan variabel. Contoh materi prasyarat dapat dilihat pada Gambar 2. 


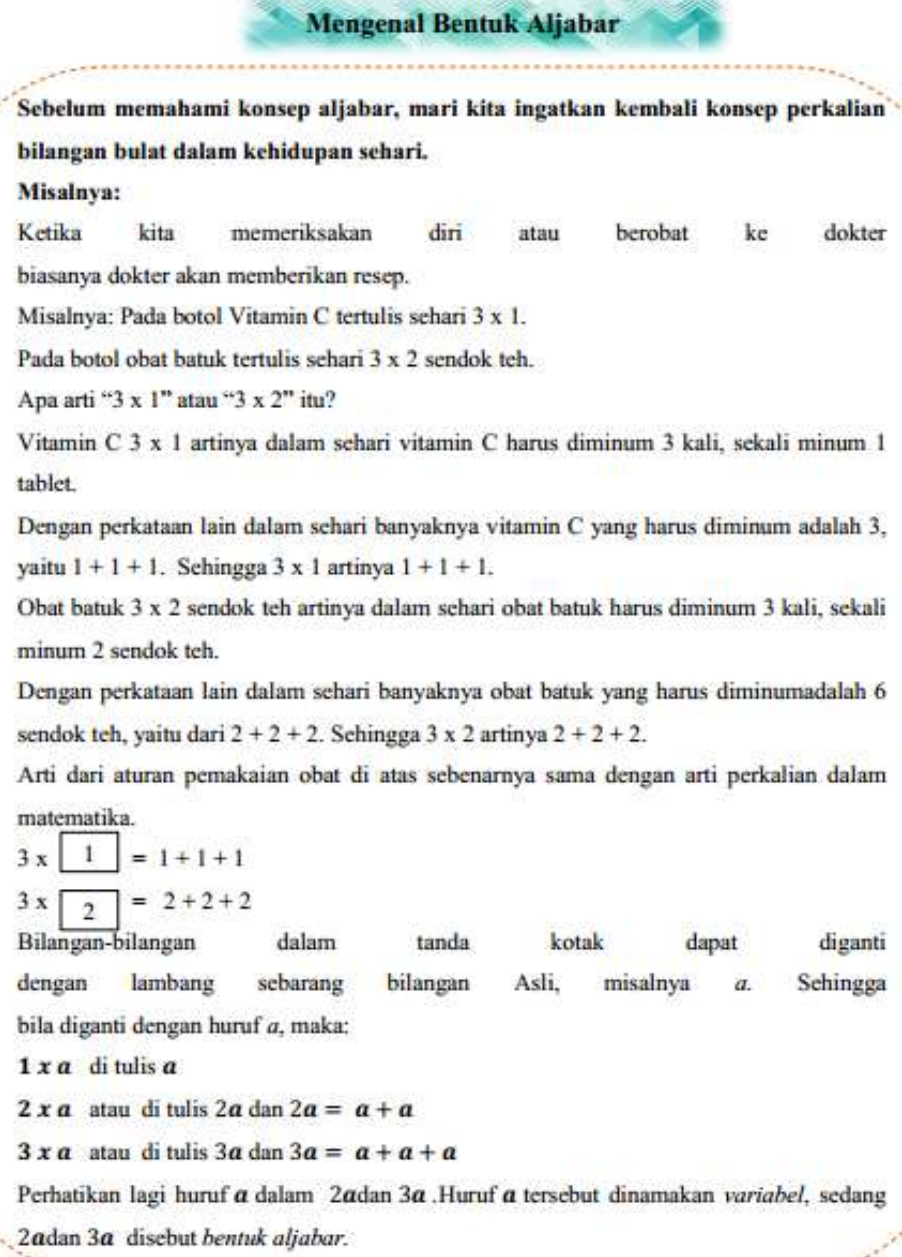

Gambar. 2 Pengetahuan Prasyarat untuk Mengenal Bentuk Aljabar

Pada Fase 1 PBL, orientasi masalah, peserta didik diminta membaca dan memahami masalah secara individu, supaya ketika siswa berdiskusi dengan teman kelompoknya untuk menyelesaikan masalah yang diberikan, siswa sudah ada pemahaman tentang masalah yang diberikan dan bisa mengungkapkan ide-idenya pada saat diskusi kelompok. Contoh fase $1 \mathrm{PBL}$ pada LKS dapat dilihat pada Gambar 3. Sedankan pada fase ke 2 PBL, mengorganisasi siswa untuk belajar, siswa diminta berdiskusi dengan teman kelompoknya untuk menyelesaikan masalah yang ada pada LKS, dari permasalahan yang mereka selesaikan diharapkan timbul pertanyaanpertanyaan. Contoh fase 2 PBL tersaji pada Gambar 4. 


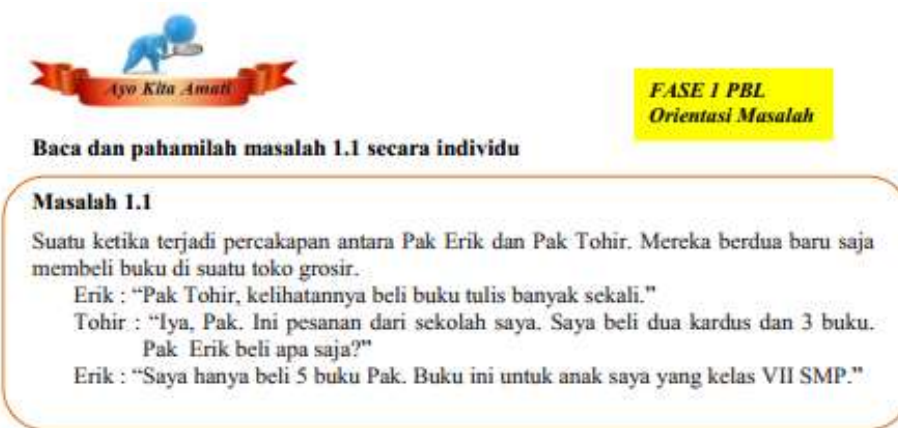

Dalam percakapan tersebut terlihat dua orang yang menyatakan banyak buku dengan satuan yang berbeda. Pak Tohir menyatakan jumlah buku dalam satuan kardus, sedangkan Pak Erik langsung menyebutkan banyak buku yang ia beli dalam satuan buku. Setelah mamahami masalah, pahami penyelesaian masalah yang disajikan pada tabel 1.1

Tabel 1.1 Bentuk Aljabar dari Masalah 1

\begin{tabular}{|l|l|l|l|}
\hline Pembeli & Pak Tohir & \multicolumn{2}{|c|}{ Pak Erik } \\
\hline Membeli & 2 kardus buku dan 3 buku & \\
& & & \\
& & & \\
\hline $\begin{array}{l}\text { Bentuk } \\
\text { Aljabar }\end{array}$ & & & \\
\hline
\end{tabular}

Gambar 3. Fase 1 PBL Pada LKS
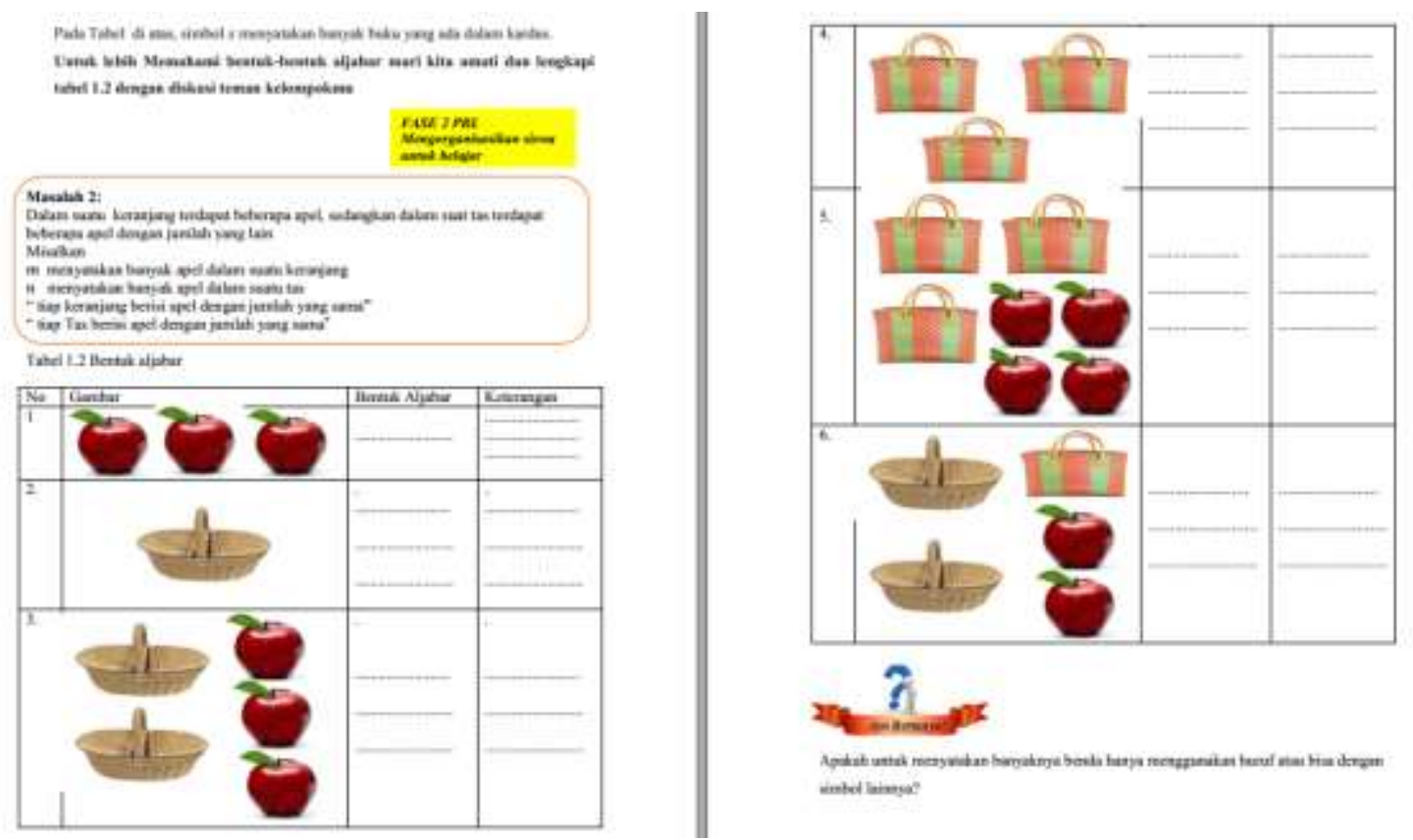

Gambar 4. Fase 2 PBL Pada LKS

Available online at Journal homepage: ejournal.iainkerinci.ac.id/index.php/edumatika Email: edumatika@iainkerinci.ac.id 
Pada fase 3, membimbing penyelidikan individu dan kelompok. Untuk menjawab pertanyaan-pertanyaan yang mereka amati dari masalah yang diberikan, siswa menggali informasi dari buku teks dan sumber lainnya. Selanjutnya mereka berdiskusi dengan anggota kelompoknya untuk menjawab pertanyaan yang diberikan. Contoh fase 3 PBL dapat dilihat pada Gambar 5.

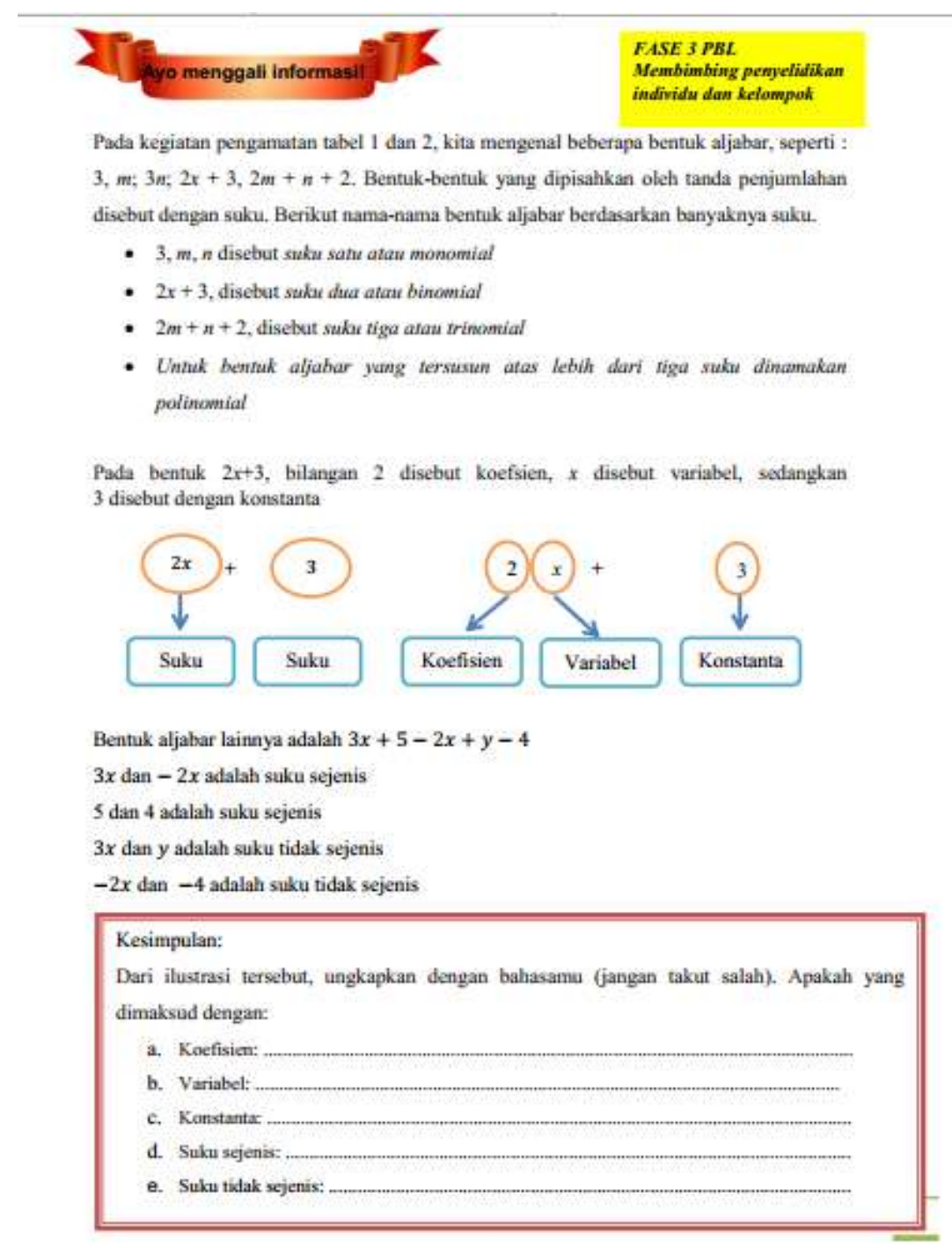

Gambar 5. Fase 3 PBL Pada LKS

Pada fase 4 PBL, mengembangkan dan menyajikan hasil karya, siswa berdiskusi lagi untuk menyelesaikan masalah yang lebih komplek dari masalah sebelumnya. Selanjutnya mereka mempresentasikan hasil diskusi kelompok mereka di depan kelas. Pada fase 3 dan 4 ini siswa diharapkan dapat memenuhi indikator komunikasi matematika yaitu mengkomunikasikan pemikiran matematika secara koheren dan jelas kepada teman, guru dan orang lain. Contoh fase 4 tersaji pada Gambar 6. 


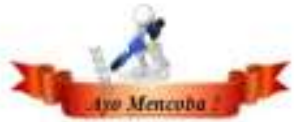

Setelah kalian melakukan kegiatan menggali informasi, sekarang coba diskusikan dengan teman kelompokmu permasalahan lain yang terdapat pada kasus berikut. Pak Tohir memiliki dua jenis hewan ternak, yaitu sapi dan ayam. Banyaknya sapi dan ayam yang dimiliki Pak Tohir secara berturut-turut adalah 27 sapi dan 1.500 ayam. Selunh sapi dan ayam tersebut akan dijual kepada seorang pedagang temak. Jika harga satu sapi dinyatakan dengan $x$ rupiah dan harga satu ayam dinyatakan dengan $y$ rupiah, tuliskan bentuk aljabar harga hewan ternak Pak Tohir.

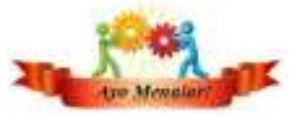

Setelah kalian melakukan keglatan mengamati dan menggali informasi,dan mencoba menyelesaikan permasahan lain, sekarang coba diskusikan lagi permasalahan yang terdapat pada kasus berikut.

1. Pada kasus Tabel 1,1, seandainya Pak Tohir membeli lagi 4 kardus buku. Bagaimanakah bentuk aljabarnya?.

2. Kemudian perhatikan kembali Tabel 1.2 .

a. Kesimpulan apa yang dapat kalian ambil dari hasil pengamatan pada tabel tersebur?

b. Pada tabel tersebut variabel $m$ untuk menyatakan banyak aped dalam suatu keranjang, dan variabel $n$ untuk menyatakan tanyak apel dalam statu tas. Mungkinkah kita membuat gambar yang menyatakan $2 x-3$ ? Jelaskan. Jika mungkin, tunjukkan.

\section{Gambar 6. Fase 4 PBL Pada LKS}

Pada fase 5 PBL, menganalisis dan mengevaluasi proses pemecahan masalah, siswa mengerjakan soal-soal latihan secara individu. Ketika presentasi teman-temannya di depan kelas, siswa bisa menganalisa dan menilai pemikiran dan strategi matematis orang lain. Sehingga pada saat mengerjakan latihan secara individu siswa dapat menggunakan bahasa matematika untuk menyatakan ide matematika dengan tepat. Contoh fase 5 dapat dilihat pada Gambar 7. 


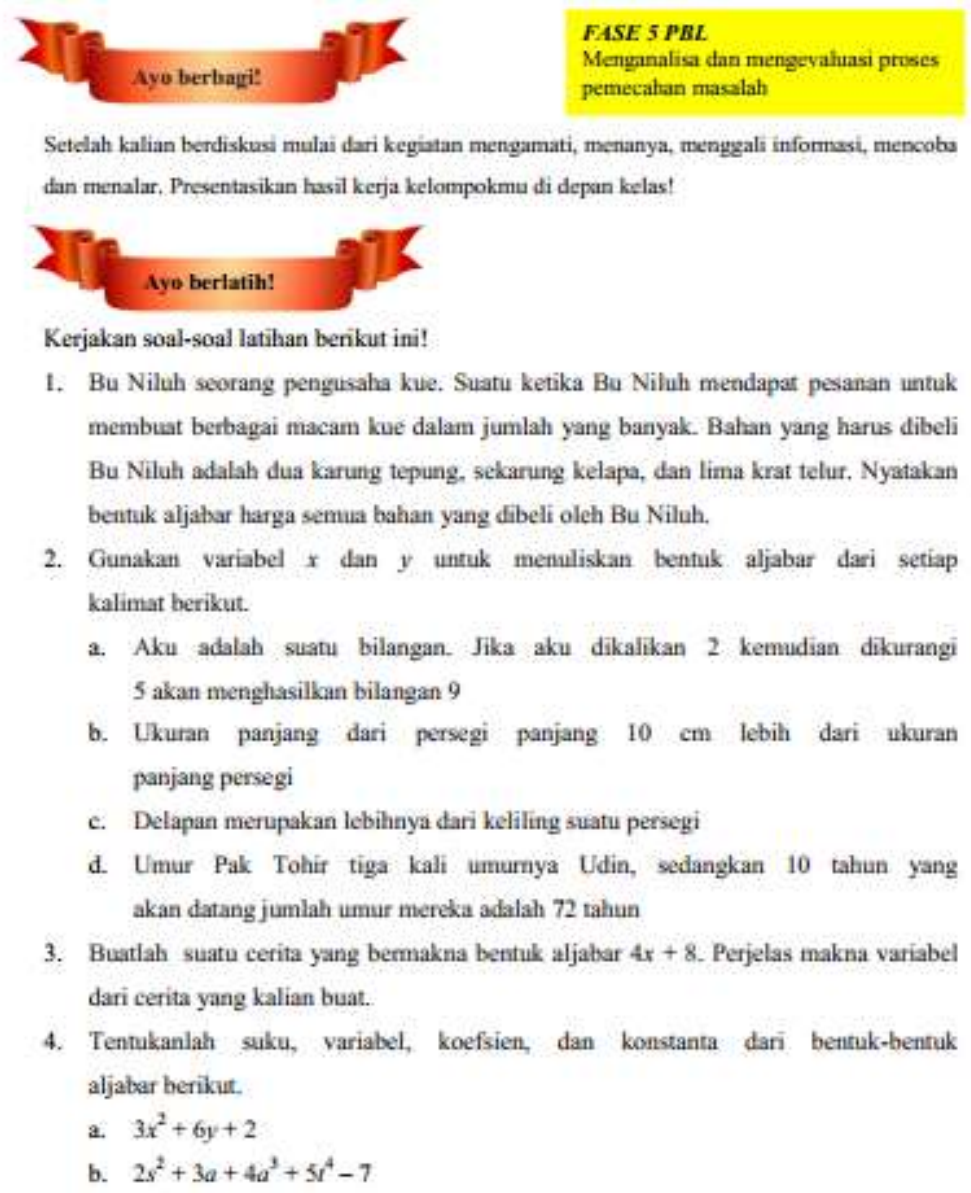

5. Tentukan suku-suku yang sejenis pada bentuk aljabar berikut ini.

a. $9 k+8 m-4 k m-15 k+7 k m$

b. $7 p^{2}-8 p^{2} q-11 p^{2}+p^{2} q+12 p q^{2}$

Gambar 7. Fase 5 PBL Pada LKS

\section{Kevalidan Perangkat Pembelajaran}

Penilaian desain perangkat pembelajaran aljabar berbasis PBL dilakukan ahli materi dan ahli desain pembelajaran. Hasil validasi ahli terhadap perangkat pembelajaran aljabar disajikan dalam Tabel 3.

Tabel 3. Hasil Penilaian Perangkat Pembelajaran Aljabar

\begin{tabular}{ccccc}
\hline No. & Aspek & Rata-rata & Kategori & $\begin{array}{c}\text { Kriteria Kevalidan dan } \\
\text { Kepraktisan }\end{array}$ \\
\hline 1. & Silabus (format, isi, dan bahasa) & 4,1 & Baik & Valid \\
\hline 2. & RPP (format, isi, dan bahasa) & 4,33 & Sangat Baik & Sangat Valid \\
\hline 3. & Desain LKS (langkah-langkah PBL) & 4,05 & Baik & Valid \\
\hline 4. & Materi LKS (materi dan bahasa) & 4,19 & Baik & Valid \\
\hline
\end{tabular}

Berdasarkan Tabel 3, perangkat pembelajaran yang dikembangkan yaitu silabus berada pada kategori valid dan RPP berada pada kategori sangat valid. Hal ini karena Silabus dan RPP yang dikembangkan sesuai dengan format dan isi yang ditetapkan pada kurikulum 2013, begitu juga dari 
aspek bahasa sudah menggunakan kalimat yang tepat dan benar, komunikatif dan tidak menimbulkan penafsiran ganda. Kevalidan desain LKS yang dikembangkan adalah rata-rata 4,05 dengan kategori valid. Hal ini karena desain LKS sudah mengikuti langkah-langkah PBL. Sedangkan kevalidan materi pada LKS dikembangkan memiliki rata-rata 4,19 dengan kategori valid. Hal ini karena materi yang disusun pada LKS sesuai dengan standar isi kurikulum 2013 dan bahasa yang digunakan sudah tepat dan benar, komunikatif dan tidak menimbulkan penafsiran ganda.

\section{Kepraktisan Perangkat Pembelajaran}

Kriteria kepraktisan diukur dari apresaisi guru dan siswa yang ditunjukkan dalam proses uji coba produk. Hasil apresiasi guru terhadap perangkat pembelajaran yang terlihat dalam proses uji coba perorangan didapatkan rata 4,23 dengan kategori sangat praktis. Sedangkan hasil apresiasi siswa terhadap LKS ini terlihat dalam proses uji coba kelompok kecil didapatkan rata-rata 3,94 dengan kategori praktis. Hasil penilaian guru dan siswa terhadap perangkat pembelajaran aljabar disajikan dalam Tabel 4.

Tabel 4. Hasil Penilaian Perangkat Pembelajaran Aljabar

\begin{tabular}{ccccc}
\hline No. & Aspek & Rata-rata & Kategori & $\begin{array}{c}\text { Kriteria Kevalidan dan } \\
\text { Kepraktisan }\end{array}$ \\
\hline 1. & $\begin{array}{c}\text { Kepraktisan perangkat pembelajaran oleh } \\
\text { guru (materi, bahasa dan format) }\end{array}$ & 4,23 & Sangat Setuju & Sangat Praktis \\
\hline 2. & $\begin{array}{c}\text { Kepraktisan perangkat pembelajaran oleh } \\
\text { siswa kelompok kecil ( isi, bahasa, } \\
\text { keefektifan, dan kegrafisan) }\end{array}$ & 3,94 & Setuju & Praktis \\
\hline
\end{tabular}

Perangkat pembelajaran dinyatakan praktis karena materi perangkat pembelajaran ini telah disesuaikan dengan $\mathrm{KD}$, indikator, tujuan pembelajaran, dan langkah-langkah pemecahan masalah pada perangkat pembelajaran mengacu pada langkah-langkah PBL. Dari segi kebahasaan, guru menyatakan perangkat pembelajaran ini telah sesuai dengan EYD, bahasa yang mudah dimengerti dan pemakaian simbol yang tepat. Selain itu juga sesuai dengan langkah kegiatan belajar yang menyenangkan dan pembelajaran tidak terjadi satu arah dari guru ke peserta didik saja, namun multi arah dari guru ke siswa dan dari siswa ke siswa. Hal ini terlihat dalam proses pembelajaran, siswa diminta untuk belajar dulu secara individu sebagai persiapan diskusi kelompok lalu mempresentasikan hasil diskusinya di depan kelas dan siswa yang lain menganalisis serta menilai pemikiran dan strategi matematis siswa lain. Kegiatan ini dapat memunculkan aktivitas komunikasi matematika baik secara lisan maupun tulisan.

Berdasarkan pendapat siswa setelah dilakukan uji coba kelompok kecil, siswa memberikan penilaian perangkat pembelajaran (LKS) sangat baik. Hal ini terlihat dari angket yang diberikan siswa memberikan nilai 4 (baik) dan 5 (sangat baik). Selain itu dilihat dari komentar siswa terhadap 
LKS yang dikembangkan, siswa menuliskan LKS ini sangat menarik, menambah minat dan motivasi belajar siswa, mudah dimengerti dibandingkan membaca buku teks, dan sangat baik digunakan. Hal ini sejalan dengan penelitian Nurbaiti (2016) bahwa model PBL juga dapat meningkatkan kemampuan komunikasi matematika dan motivasi belajar siswa. Berdasarkan data yang diperoleh melalui uji coba produk, perangkat pembelajaran ini dapat dikatakan praktis karena menurut Nieveen (1999) perangkat pembelajaran dikatakan praktis jika guru dan siswa mempertimbangkan perangkat pembelajaran mudah digunakan di lapangan dan sesuai dengan rencana peneliti. Hal ini dibuktikan dengan penilaian guru dan siswa yang menyatakan perangkat pembelajaran ini mudah dan praktis digunakan dalam proses pembelajaran.

\section{KESIMPULAN}

Hasil pengembangan perangkat pembelajaran aljabar berbasis PBL yang mendukung kemampuan komunikasi siswa SMP berdasarkan bernilai valid menurut hasil validasi ahli desain, sangat valid menurut hasil validasi ahli materi, sangat praktis berdasarkan respon guru dan praktis menurut respon siswa. Karakteristik perangkat pembelajaran yang dikembangkan sudah sesuai dengan langkah-langkah PBL dan dilengkapi dengan strategi yang menfasilitasi siswa untuk mengkomunikasikan ide-ide matematika kepada sesame siswa dan guru.

\section{DAFTAR RUJUKAN}

Anggralia, R., Deswita, R., Erita, S., Habibi, M., \& Putra, A. (2019). Effect of Model-Eliciting Activities (MEAs) Approach on Students' Mathematical Communication Skills. Edumatica: Jurnal Pendidikan Matematika, 9(02), 41-49.

Deswita, R., Kusumah, Y., \& Dahlan, J. (2018). Peningkatan Kemampuan Komunikasi Matematis Siswa Melalui Model Pembelajaran CORE dengan Pendekatan Scientific. Edumatika: Jurnal Riset Pendidikan Matematika, 1(1), 35-43. doi:10.32939/ejrpm.v1i1.220

Duskri, M., Maidiyah, E., Risnawati, R., \& Ilham, S. (2017). Penerapan Model Problem Based Learning untuk Meningkatkan Kemampuan Komunikasi Matematis dalam Pemecahan Masalah Di Kelas IX-6 SMPN 8 Banda Aceh. Al Khawarizmi: Jurnal Pendidikan dan Pembelajaran Matematika, 1(1), 75 101.

Elita, G. S., Habibi, M., Putra, A., \& Ulandari, N. (2019). Pengaruh Pembelajaran Problem Based Learning dengan Pendekatan Metakognisi terhadap Kemampuan Pemecahan Masalah Matematis. Mosharafa: Jurnal Pendidikan Matematika, 8(3), 447-458.

Kumala, A. J., Waluyo, S. B., \& Siswanto, B. (2019). Implementasi Model Problem Based Learning untuk Meningkatkan Kemampuan Komunikasi Matematis dan Percaya Diri Siswa Kelas X Sma Negeri 4 Semarang. In PRISMA, Prosiding Seminar Nasional Matematika, 2, 410-415.

Nieveen, N. (1999). Prototyping to Reach Product Quality. Jan Van den Akker, Robert Maribe Braneh, Ken Gustafson, and Tjeerd Plomp (Ed). London: Kluwer Academik Plubishers.

Nur, M. (2011). Model Pembelajaran Berdasarkan Masalah. Surabaya: Pusat Sains dan Matematika Sekolah UNESA.

Sanjaya, W. (2011). Perencanaan dan Desain Sistem Pembelajaran. Jakarta: Kencana.

Sartika, R. (2017). Pengaruh Penerapan Model Problem Based Learning Berbantuan Media Pembelajaran Interaktif terhadap Kemampuan Komunikasi Matematika, Kemampuan Penalaran dan Kemampuan 
Pemahaman Konsep Matematika bagi Siswa Kelas X MAN 1 Kota Bengkulu. Jurnal Pendidikan Matematika Raflesia, 2(1), 108-117.

Soedjadi. (2000). Kiat Pendidikan Matematika di Indonesia. Jakarta: Depdiknas.

Nurbaiti, S. I. (2016). Pengaruh Pendekatan Problem Based Learning terhadap Kemampuan Komunikasi Matematis dan Motivasi Belajar Siswa (Penelitian Eksperimen terhadap Siswa Kelas V SDN Sindangjati dan SDN Bongkok Kecamatan Paseh Kabupaten Sumedang). (Doctoral dissertation, Universitas Pendidikan Indonesia).

Supatmono, C. (2009). Matematika Asyik, Asyik Mengajarnya. Jakarta: Grasindo.

Izzati, N., \& Suryadi, D. (2010). Komunikasi Matematik dan Pendidikan Matematika Realistik. In Prosiding Seminar Nasional Matematika dan Pendidikan Matematika, 27, 721-729.

Thiagarajan, S. S. (1974). Instructional development fortraining teachers of exceptional children: A sourcebook. Bloomington, Indiana: Indiana University.

Wulansari, T., Putra, A., Rusliah, N., \& Habibi, M. (2019). Pengaruh model pembelajaran berbasis masalah pada materi statistika terhadap kemampuan penalaran statistik siswa. AKSIOMA: Jurnal Matematika dan Pendidikan Matematika, 10(1), 35-47. 